\title{
Culture Matters: Confucian Virtues and Economics
}

\author{
Chris Larsen* \\ Hankuk University of Foreign Studies, South Korea
}

*Corresponding Author: Chris Larsen, Hankuk University of Foreign Studies, South Korea

\begin{abstract}
There has been a long-standing debate about the potential within East Asia to perform and participate in the modern global economic system of recent decades. It has been unclear whether newcomer states would adopt to international norms or create new ways of engaging with the global economy. As recent decades have shown, the rise and development of East Asian economies in so-called Confucian countries, clarifies that such states are economically viable. Yet why any given state can succeed is a complex and multifaced question not so easily answered. Why the Confucian economic "miracles" in particular were so extraordinarily successful is a related question that many scholars have taken to exploring. This brief study analyzes these studies to find patterns that can help particular why Confucianism appears to foster economic development, and the role of culture to that end. The findings also shed light on how the Western world compares, in terms of values, as states globally continue to modernize and advance. The study concludes with some implications of the findings that will be useful for further research and consideration.
\end{abstract}

Keywords: Confucianism, Development, Values, Culture, Progress

\section{INTRODUCTION}

Despite the Asian financial crisis of the late '90s, East Asia has made remarkable progress and socioeconomic development. More than fifty years ago, the richest average citizen in the region, one of Japan, earned a fraction of that of their American counterpart. South Korea had the wealth of Sudan, and Taiwan that of Zaire (Rowher, 1995, p.28).Soon, an unexpected transformation occurred and by 1993 the World Bank reported that no other class of developing states had performed as effectively in promoting growth, addressing poverty, coming into sync with world markets, or improving the quality of life. The publication noted that percapita incomes in the region experienced nearly fourfold growth in just a quarter century. On the average, rapid population rates receded along with poverty dropping more than $60 \%$, coinciding with better health and education outcomes. This first round of successes if the so called "Asiantigers" has now recently led to a second wave of rapid industrialization and economic growth, with China joining in.

Meanwhile, an ocean away, the story was quite a different story. Before 1955, Brazil was already well ahead of South Korea and Taiwan and emerging with import substitutions, like Mexico. However, within three decades, the Latin American financial boom was essentially over, transitioning into the "lost decade' of the 1980s. What is the reason for such stark differences in the socioeconomic development of regions with similar circumstances? To answer the question, scholars have employed numerous approaches, one being somewhat taboo in the form of culture. By now however, the underlying question is no longer if culture matters, but rather how culture matters. How significant could cultural factors be in the economic performance of a region? By what standard is assessing the connection between culture and socioeconomic advancement measured?

\section{METHODS}

This paper contributes to an ongoing series of studies that look at the role of culture on development, and specifically engages with how Confucianism has played a role in the socioeconomic development in East Asia. This study employs a qualitative comparative case study analysis of the secondary source materials to glean insights into the roles of culture and values in the East Asian context.

\section{BACKGROUND}

\subsection{Culture and Development}

Culture has been evaluated from many vantage points, typically in ways that best serve the ends of the evaluator. It is clear though that lines must be drawn somewhere to make a discussion about culture 
manageable, and the range is vast. Perhaps the earliest usages of something "cultural" are linked to human's first trials with "agri(culture)". Later, culture perhaps describes the more highly refined aspects of class and society where someone "with culture" could be perceived as an individual of greater worth than someone without. Surely is has been true since the dawn of civilization that having certain attributes has given privileged members in a society higher status that others. Yet it is recent history where "culture" beings to take a more complex form. Not until the 1700 s, is there is seems the initial use of the word as a noun and implying that all people actually possess something called 'culture' (Bennett, 1995, p.14-15).

As for such times, rather broad definitions of culture worked quite well: "that complex whole which includes knowledge, beliefs, art, morals, law, customs, and any other capabilities and habits acquired by man as a member of society" (Alexander and Kumaran, 1992, p.11). However, the more culture has become a significant variable the less such vague and unmanageable definitions become useful. Of course, certain elements seem essential, like values, social heritage, and the various acquisitions innate in being part of a society (ibid, p. 11-12), which suggests that human values are the essential characteristic in culture and therefore belief and behavior.

Yet there are still other aspects of culture like amassed knowledge, technology, religion, ideology, rituals, skill sets and artifacts (ibid, p.12). Lawrence Harrison described culture "as a set of values and attitudes that guide the actions of individuals and the interaction of people within a society." Whereas "values" reflect the norms to which a society gives significance, and "attitudes" as the way members learn to respond to "facts, circumstances, and issues" (Harrison, 1997, p. 31).

Meanwhile, North viewed culture through the lens of institutional structures and change. "In all societies from the most primitive to the most advanced, people impose constraints upon themselves to give a structure to their relations with others. Where do informal constraints come from? They come from socially transmitted information and are a part of the heritage that we call culture. Culture can be defined as the 'transmission from one generation to the next, via teaching and imitation, of knowledge, values, and other factors that influence behavior"'. In Trust (1995), Fukuyama describes culture using "inherited ethical habit." He posits the denotation most resembles the generally understood meaning (Fukuyama, 1995, p.34).

In Huntington's well-know The Clash of Civilizations? a number of "civilizations" are listed, including two which are Confucian (Huntington, 1993). This seems counterintuitive, but Huntington explains "A civilization is a cultural entity. Villages, regions, ethnic groups, nationalities, religious groups, all have distinct cultures at different levels of cultural heterogeneity...A civilization is thus the highest cultural grouping of people and the broadest level of cultural identity people have short of that which distinguishes humans from other species. It is defined both by common objective elements, such as language, history, religion, customs, institutions, and by the subjective self-identification of people." The argument further explains that a "civilization may involve a large number of people, as with China, or a very small number of people. A civilization may include several nations' states, as is the case with Western, Latin American and Arab civilizations, or only one, as is the case with Japanese civilization" (ibid, 1993).

It seems apparent from these divergences then, that culture is not so easily defined. And yet "culture", as a noun, is ubiquitous in both scholarship and everyday life (Bennett, 1995, p. 14). This alone is a strong indicator that clarification and limitations must be established when attempting to make culture have meaning in an academic discourse such as this. For the purpose of this writing, culture is framed in terms of a tradition, since the topic is Confucianism, the description would be those elements a society carries over from its history, that shape ethical norms, notions of value, ways of behaving and thinking, as well as how to live, what habits to adhere to, notions of aesthetics, and so on. Such elements form the basis for the unique cultural fingerprint in a particular society.

\subsection{The Workings of Development}

One of the central modern assumptions among states and international institutions is that development and peace should be central goals. While some still emphasize the need to fix dependency, colonial domination, and abuse, where exchanges were imbalanced, and a fair economic exchange was missing. However, with more than a billion people being pulled out of global poverty since the 1990s, it seems important to being now looking more at internal factors contributing to development as well. 
Although development results from forces both within and without, there are many instances when the internal variables are more significant and deciding.

Among the available internal factors in economic development, there is an increase in focus on reasons independent of economics, such as culture. As Harrison paraphrased from Bondy, "Underdevelopment is not just a collection of statistical indices which enable a socio-economic picture to be drawn. It is also a state of mind, a way of expression, a form of outlook and a collective personality marked by chronic infirmities and forms of maladjustment" (Harrison, 1985).

When it comes to Confucianism and a comparative analysis of cultures in East and West, Max Weber was certainly early to study the linkages between culture and development. In The Protestant Ethic and the Spirit of Capitalism (1905) and The Religion of China: Confucianism and Taoism (1951) Weber suggested that certain values were linked to cultural underpinnings and hence behavior and development. The Protestant ethics were values such as diligence, frugality, integrity, rationality and precision, which were labeled as the foundation of attainment and economic development. To illustrate, Weber wrote, "When the limitation of consumption is combined with this release of acquisitive activity, the inevitable practical result is obvious: accumulation of capital through ascetic compulsion to save. The restraints which were imposed upon the consumption of wealth naturally served to increase it by making possible the productive investment of capital" (Weber, 1958).

Just Harrison was concerned with underdevelopment, Myrdal too explored the topic in Asian Drama (1968), concluding that the primary hinderances to development are cultural. It is not simply that cultural elements prevent business interactions, but instead they saturate, stiffen and control the entirety of a nation in all aspects ranging from political to economic to social. People are habituated to certain ways of being and guided by staunch mental models stemming from the population with whom they live. Myrdal explains, "The conflict between articulated specific traditional valuations and the modernization ideals can be expressed in terms of the costs to the latter through lost opportunities" (Myrdal, 1968).

Another with a similar argument is Lewis in The Theory of Economic Growth (1955). Here, culture is tethered to development from a more macroscopic view of the sociopolitical backdrop. He states, "Economic growth depends on attitudes to work, to wealth, to thrift, to having children, to invention, to strangers, to adventure, and so on, and all these attitudes flow from deep springs in the human mind" (Lewis, 1955, p.14).

Ethnographic and field research have also long been a staple for researchers seeking the linkages between culture and economic development. Edward Banfield, one of the pioneers in the field, based observations on a underdeveloped community in southern Italy a decade after WWII ended. Banfield noted, "We are apt to take it for granted that economic and political associations will quickly arise wherever technical conditions and natural resources permit... The assumption is wrong because it overlooks the crucial importance of culture" (Banfield, 1958, p.8).

Similarly, Lawrence Harrison, who spent years in Latin America as a representative of USAID, stated "It is culture that principally explains, in most cases, why some countries develop more rapidly and equitably than others" (Harrison, 1985, p. xvi.). In his book covering Latin America, The PanAmerican Dream, Harrisone laborated on how progress-prone and progress-resistant cultures differ in their attitudes concerning aspects of society like time, work, frugality, education, achievement, community, morals, integrity, authority, and religion (Harrison, 1997, p.32). These ideas would then be further developed later in his books The Central Liberal Truth and Culture Matters.

However, culture may be defined, it appears certainly mirrored in the sociopolitical and economic spheres of society. It is a force that shapes meaning, and influences values garnered from history, tradition, and a myriad other element. Hall and Hall put it well in saying that "culture can be compared with a giant, extraordinary complex, subtle computer. Its progress guides the actions and responses of human beings in every walk of life.” (Hall, Hall, 1990, p.3).

\section{ReSUlts}

\subsection{East Asian culture}

Modernization can be broadly understood in terms of phases. Certainly, the Industrial Revolution (1760 to mid-1800s) is the best candidate for the first phase, with Europeans taking center stage. 
Phase two follows up until the early 20th century, which is marked by. Eastern Europe, North America, and Latin America being drawn in. The last wave follows World War II, which pulled in Asia, Latin America, and parts of Africa. This last wave has East Asia at the center of this rapid industrialization and modernization.

From the lens of culture, these waves of modernization moved from predominately Christian societies, and then more broadly into states with a plurality of Christian ideologies (with the exception of Japan), and then finally in the Confucian world (with Latin America lagging somewhat behind). What is notable about East Asia is that while the states are far from culturally homogeneous, or even similar, yet Pye explains "the political features that the East Asian systems have in common are. . . their shared Confucian cultural traditions" (Pye, 1988, p.82). It is in fact Confucianism, nearly alone, that binds together the East Asian cultural arena.

Yet Confucianism arouses a great deal of debate and hostility as traditionalists and modernists lock horns over identity, history, and the promulgation of modernization. In China, for example, the government was very effective at campaigning against Confucianism as a handicap and the reason for seemingly all of China's various woes. This was particularly robust when China was reshaping its economy toward a market-driven design. Such a view is offset in China by those who think Confucianism will have a resurgence for the Chinese identity and provide a new ethical model for modern global societies. Meanwhile, South Korea seems to have not had such a debate and simply embraced its Confucian roots. One need only look at the money, which is adorned with Confucian scholars.

What is important to understand in comparing perspectives on Confucianism in East Asia, is that as with Christianity in Europe, there is much that is highly engrained and embedded into the languages and cultures of East Asia from millennia of Confucianism influence. Whether the elements and values are helpful or not, they are certainly the bedrock of mental models and normative conduct of the people and their cultures. It is inevitable then that Confucianism will continue to participate in East Asian modernization. It is therefore essential to better understand how this can best be understood to better predict how the third wave will unfold and the role East Asia will play. To this end, some energy will be spent to elaborate on the Confucian virtues and identify how they can meaningful help or hinder modernization, especially in terms of economic development, which relies heavily on trust and social capital. It may be then possible infer a few generalizations about the modernization process in Confucian states.

\subsection{Confucianism and Modernization}

It is important to understand that the scope of Confucianism covers a great deal of time. Confucius' legacy has spanned nearly 2,500 years, so it is necessary to limit the aspects to those elements that are still relevant today and how they conflict or contribute to the modernization process. The primary areas where Confucianism creates challenges in East Asia are described below.

\section{Confucianism}

1. Peasant economy

2. Particularism

3. Classism

4. Patriarchy

5. Traditionalism

6. Inward looking

7. Uphold Virtues

8. Thrift and Self-control

9. Community

\section{Modernism}

Market economy

Rule of law

Equality

Democracy

Creativity

Outward looking

Materialism

Consumption and Hedonism

Individual

*The summary here is that Confucian economics should depend on harmony, and adherent to natural laws, but that gives people superiority. Extremes should be avoided as well, and as such, economics should work to reduce greed and a main cause: inequality. Making money can be accomplished in 
wholesome ways and by frugal living, having integrity in business, and through diligence. The government should help with wealth creation through policy formation, agriculture, and pulling citizens from poverty. It is therefore most effective for government to be centrally controlled and efficient. In all cases, economic activities and living should coincide with moral behavior, which can be anchored in the Confucian Virtues.

In addition, there are a number of worthwhile critiques of Confucian ethics, such as Kahn in World Economic Development: 1979 and Beyond, "First and perhaps foremost, Confucian societies uniformly promote in the individual and the family sobriety, a high value on education, a desire for accomplishment in various skills (particularly academic and cultural), and seriousness about tasks, job, family, and obligations. A properly trained member of a Confucian culture will be hardworking, responsible, skillful, and (within the assigned or understood limits) ambitious and creative in helping the group (extended family, community, or company). There is much less emphasis on advancing individual interests" (Kahn, 1979, p.121)

A similar account comes from Engholm, "Confucianism inculcates servility, frugality, abstinence, and diligence. It recognizes hard work, patriarchal leadership, entrepreneurial spirit, and familial devotion" (Engholm, 1991, p.25). What is striking is that Confucian values include an emphasis on merit and achievement, hence the importance of thrift, hard work, and education. What is curious is that these are also the qualities which Max Weber described as a Protestant ethic, which was instrumental to the development of Western capitalism (Lee, 1993, p.18).

Yet it is also true that the Chinese have not always had a positive view of their Confucian roots and have frequently perceived it as a hinderance to Chinese development. When Weber was studying East Asia and Confucianism, he surmised that the virtues upheld in East Asian doctrines helped elucidate why their development lagged behind Europe. He contended that the Confucian value system didn't give rise to the sort of anxiety, or craving for achievement, as could be seen in the Protestant ethic.

Irrespective of this contest concerning the influence of Confucianism on modernism, it is still possible to infer three areas where economic development is bolstered by Confucianism. Certainly, the prima facie evidence suggests that since Confucian states have proven themselves economically and developmentally capable, then at least Confucianism isn't an impediment. However, the determination of support from Confucianism comes from the following:

1) Confucianism values frugality and saving, which leads to economic security and expanded investments. Supply and demand stipulate that a surplus can bolster the productivity of an economy. It is further well-established that development growth is dependent on cash injections toward investments that take the shape of the kind of infrastructure and technology that allows for economic expansion. From1965-1990, investments in East Asia were comparable to those in Latin America ( 20\%/GDP) at the onset, but by the end East Asian rates ballooned to 35\%: more than double that of Latin American (Rohwer, 1995, p. 54-55). Similarly, the propensity of indivuals and corporations to save money was quite high in East Asia, which would eventually be transmuted into investment instruments. During the same time period discussed, saving was $~ 16 \% / G D P$ at the onset in East Asia (below Latin America), but nearly double Latin America at 35\%/GDP by 1990. It is well understood that high levels of saving correspond to growth and development, which in turn bolters incomes and further saving, which again fosters investment, in a continuous reinforcing loop.

2) Confucianism highly values education, which is another form of investment. East Asia nations have associated education with personal success and wealth for centuries. Confucian society was also classist with the most educated "scholarly gentleman" at the top. Lower classes could aspire to raise their station, or that of their children, but mainly though acquiring education. It should not be much of a surprise that data increasingly demonstrates a significant parallel between academic attainment and wealth cultivation. In terms of country development as well, education is converted into a resource in the form of human capital, which some argue is the essential basis of any country's prosperity and ability to apply one's knowledge to everything from mining, to the laws, toward building, or in organizing, etc... (Alexander, and Kumara, 1992, p.19).Education also "1) improves the quality of labor through promotion of skills, efficiency and work knowledge; 2) increases labor mobility to promote division of labor and to strengthen the labor force participation rates; 3 ) increases scientific and technical knowledge to promote invention and rapid adaptability; 4) increases the ability of entrepreneurs to improve management and the allocation of production factors; and 5) makes people 
more responsive to economic change and remove social and institutional barriers to economic growth" (Kim, 1989, p.530).

3. Confucianism emphasizes work. The meaning of a "work ethic" is various, but its essential features include: "1)work as an end in itself, which is expected to bring the reward of material success; 2) pride in good quality workmanship, hard work, an instinct of workmanship and satisfaction in work; and 3) adherence to the discipline of work, namely, punctuality, obedience, diligence, industriousness" (Barbash, 1983, p.136).

It certainly makes logical sense for one designing the social virtues for an agrarian society to live by, to make hard work a virtue, and laziness a vice. The former corresponds to high moral character, while the latter produces depravity and disgrace. While many East Asians may not be familiar with Confucian scripture, the lessons, legacies, and traditions have been well maintained in the minds of people. Working hard is certainly still considered a virtue. Hitchcock's "Asian Values and the United States", asked those surveyed to rate what virtues they considered to be "critically important", and "hard work" topped the list (Naisbitt, 1996, p.54).

\section{DISCUSSION}

The Asian Financial Crisis of the late '90s appeared to suggest that Weber was right, and that the Asian economic 'miracles' were transitory as country after country began to face hardships. The discussion turned quickly to the possibility that Asian values contributed to rife corruption, fiscal nepotism, intrusive government encroachment, and a profound disregard for transparent economic practices. Yet Fukuyama resisted this urge in stating, "From being the cause of Asia's success, Asian values are now seen (by some people) as the root of last summer's currency crisis of the ensuing economic meltdown across nearly the whole region. Neither reading is correct" (Fukuyama, 1998, p.8). In fact, the causes appear subtler and rooted in inexperience as much as misguided behavior such as overreach on capital evaluations, maintaining excessive trade imbalances, reducedglobal competitive edge, and over-speculation. With either argument however, as Lucian Pye has indicated, while "there is no example in history to match the dramatic reversals in fortune of the Asian economies during the second half of the twentieth century..", "yet the collapse of the "miracles" should not end the discussion about "Asian values", but should ignite a more sober and critical analysis of the importance of values in producing sustainable economic development" (Harrison, 1995, p.8).

From this, it may be possible to continue the discussion and evaluation of variance of aspects of cultures and the areas differences in economic performance. Confucianism is certainly not the only explanation for East Asia's successes, nor Latin America's lack thereof, but their significance is undeniable and allows certain limited conclusions to be drawn.

First, allowing for the explanatory power of culture to play a role, an alternative narrative concerning economic performance at various locals around the world can see the light of day. The goal of is not to deconstruct economic progress to a finite set of cultural culture values or country characteristics. The issue is the extent to which culture can influence economic development and be understood as a reflected in things like policy choices or institutional design. Then it is easier to understand the connections between the two (So and Chiu, 1995, p.8). Put another way, culture can offer scholars a lens with which to see how values and behaviors cans way economic development in certain directions, not just in East Asia, but anywhere.

Second, although the vast range and significance economic factors are important, they exist between societies, communities, and people in general, which are governed fundamentally by culture. While "the invisible hand", as Adam Smith put it, may in guiding self-interest sway geopolitical factors, policy, economic behavior, and institutional practices, the owner of the self-interest is regulated by culture.

Third, each culture is a social construct of perceived pros and cons. These elements do not create positive financial performance by default and without other required ingredients like intelligent fiscal policy, competent institutional management, supportive global financial conditions, or apt judgement and timing. This means that the necessary and sufficient conditions need be meet for culture to have a particularly robust and observable effect. This helps articulate how China can go from "the sick man of Asia" to having the second largest country GDP. As Pye again states, "the same values, operating, 
however, in quite different circumstances, can and usually will produce different effects" (Harrison, 2001, p.245). Circumstances, economics and culture are all powerful forces guides by different forces and principles yet are all fundamentally dictated by what underlying values are present in each.

\section{CONCLUSION AND IMPLICATIONS}

This paper has attempted to look at culture and socioeconomic progress with East Asia and Confucianism the targets of analysis with a limited scope. The interplay between culture and economic progress in East Asia, particularly the significance of how the Confucian virtues, has spurred on many questions regarding trust and social capital and how East Asia (especially the Four Tigers) could seize upon the opportunities of development. Modern neoclassic economic theory has generally come to the conclusion that individuals behave out of "utility-maximizing rational selfinterest" (Fukuyama, 1998, p. 18). So, individuals desire to maximize their material well-being with primacy over other dimensions of life. While this apparently holds true about eighty percent of the time, it seems to be a very narrow view of human life which doesn't include the significance of culture or social life (ibid, p. 13), which one may consider to roughly constitute the other twenty percent. Individuals do not always act in terms of material gain, but often seek nonutilitarian goals associated with recognition, religion, justice, prestige and honor (ibid, p.19). It should be further noticed that economics takes place within social interactions, so it's impossible to try to define economic behavior without consideration for human behavior. This then seems to indicate that there has been an oversight in neoclassic economic theory in that is doesn't well include how culture and social values affect economic behavior and socioeconomic progress. As Fukuyama points out in "culture shapes all human behavior, including economic behavior" (ibid, p.18) whereupon he points to trust, social capital and spontaneous specialization as the interrelated elements that are required for socioeconomic progress and are the foundation for the other twenty percent of life. This 80-20 postulate for development is interesting for two important reasons. First, although eighty percent of the time may correspond to utility-maximizing rational self-interest, and twenty percent to cultural and social life, these are still described in terms of time and it is unclear how much one effects the other based upon the decision-making processes rooted in values. The $80 \%$ in all likelihood may rely on the $20 \%$ to even function. Secondly, the potency or worth of a value in a society may exist, even if ignored, and yet still have profound far-reaching effects for good or bad depending on the circumstances. "Cultural values are always clusters of values that at different times can be combines in different ways and thus produce different effects" (Harrison, 1995, p. 245).

\section{IMPLICATIONS}

"In the emerging world of ethnic conflict and civilizational clash, Western belief in the universality of Western culture suffers three problems: it is false; it is immoral; and it is dangerous...Imperialism is the necessary logical consequence of universalism."(Huntington, 1996, p. 310)

The recent and steady decline of Western societies contrasted to the rapid advancements observed in Asian Confucian states, has been regarded by many as a concern for the social and economic future of Western countries. Liberal democratic ideas and institutions helped act as a stabilizing force for social structures and cultural ethos that supported wide-spread trust and social capital for rapid economic development in the past. But since then, extensive individualism created in the West, especially in the United States, has bloated to such a degree that is has become, as Harrison describes, a ProgressResistant trait. The seemingly ongoing revelations of government deception and corporate scandals sit on a long list of recent blemishes that have surfaced in liberal democratic societies globally. The destructive impact to the Progress-Prone value sphere, previously common in the West, has been so great that progress and advancement have slowed dramatically. Meanwhile, although arriving late, the Confucian states like South Korea developed pro-democratic politics and institutions rapidly to complement their existing civil societies. Having here considered the relevance of culture to economics, especially among Confucian states, the West should take heed the lessons as well if they wish to stay among the world's most powerful and influential.

Edward Romar in, "Globalization, Ethics, and Opportunism: A Confucian View of Business and Relationships" suggests that opportunism is to blame. Opportunism is the unethical height of selfinterest and extraordinarily Progress-Resistant since it can rapidly break apart trust and social capital. Romar believes that Confucianism can help solve some of these problems the West now faces. After all, when US manufacturers were losing ground to Japanese lean production methods in the 1980s, the 
US learned the lesson and adopted the strategies and added their own innovations, with notable success. There is no reason the same strategy can't be followed regarding some elements of Confucianism and offer the same kinds of assistance to certain areas of western society.

"Confucianism can help solve this ethical dilemma because it recognized that self-interest is a basic human motivation and presents important ethical issues. Confucianism is based upon virtues of trust, honesty and benevolence and is relational and hierarchical. Thus, Confucianism is well suited to opportunistic challenges both within and among organizations." "Confucianism [also can be] an ethical solution to the challenge of opportunism in the global business environment because it can offer a moral foundation to the increasingly more interdependent relationships characterizing business behavior in an interrelated and global economy" (Romar, 2004).

In this way Confucianism can require a moral person to focus more intently on their motivations and to develop virtue, while holding the immoral in check, so long as the policy is constructed so. Romar offering Confucianism as a moral structure for business platforms is also just one idea, perhaps among numerous other unforeseen applications. Further study should consider how to use institutions and policy to systematically support civil society and the associated cultural elements of trust and the Progress-Prone virtues, if the West wishes to maintain its position among the global "elite". Otherwise, the continual Progress-Resistant trend will continue to influence priorities and conduct, such as toward long-term planning, investing, study, or self-discipline, toward untold unfavorable and unintended consequences.

\section{REFERENCES}

[1] Alexander K. C. and Kumaran P. P.Culture and Development: Cultural Patterns in Areas of Uneven Development. New Delhi: Sage Publications, (1992).

[2] Banfield, Edward. The Moral Basis of a Backward Society, The Free Press, (1958).

[3] Barbash, Jack et al. eds.: The Work Ethic - A Critical Analysis, Industrial Relations Research Association, p. 233, (1983). Cited from David A. Levin and Sze Yeung: The Hong Kong Work Ethic, in Ian Nish, Gordeon Reading and Ng Sekhong. eds.: Work and Society: Labour and Human Resources in East Asia, Hong Kong University Press, (1996).

[4] Berger, Bennett. M. An Essay on Culture: Symbolic Structure and Social Structure. University of California Press, (1995).

[5] Fukuyama, Francis. Trust: The Social Virtues and the Creation of Prosperity. The Free Press, (1995).

[6] Fukuyama, Francis. Asian Values and the Asian Crisis, in Commentary,February, 1998.

[7] Engholm, Christopher. When Business East Meets Business West: The Guide to Practice and Protocol in the Pacific Rim, John Wiley \& Sons, New York, (1991).

[8] Hall, Edward T. and Hall, Mildred Reed. Understanding Cultural Differences, Intercultural Press, Inc., (1990)

[9] Harrison, Lawrence. Culture Matters: How Values Shape Human Progress. New York, N.Y: Basic Books, (2001).

[10] Harrison, Lawrence. The Pan-American Dream- Do Latin America's Cultural Values Discourage True Partnership with the United States and Canada, Basic books, (1997).

[11] Harrison, Lawrence E. Underdevelopment Is a State of Mind, University Press of America, (1985).

[12] Huntington, Samuel P. The Clash of Civilizations?, in Foreign Affairs. Summer,(1993)

[13] Huntington, Samuel P. (1996) The Clash of Civilizations and the Remaking of World Order. Touchstone. New York, NY.

[14] Kahn, Herman. World Economic Development: 1919 and Beyond, Westview Press, (1979).

[15] Kim, J. W. The Role of Education in Economic Development - The Korean Experience, in W. Klenner (ed. ): Trends of Economic Development in East Asia, Springer-Verlag, (1989).

[16] Lee, Keun. New East Asian Economic Development -Interacting Capitalism and Socialism. Taylor \& Francis, (1993).

[17] Levin, David A. and Yeung, Sze. The Hong Kong Work Ethic, in Ian Nish, Gordeon Redding Nd Ng Sekhong (eds. ): Work and Society: Labour and Human Resources in East Asia, Hong Kong University Press, (1996).

[18] Lewis, W. A.The Theory of Economic Growth, Richard D. Irwin, Inc., (1955)

[19] Lie, John. The Political Economy of South Korean Development, inInternational Sociology. September 1, 1992. 
[20] Naisbitt, John. Megatrends Asia: Eight Asian Megatrends That Are Reshaping Our World, Simon \&Schuster, (1996).

[21] North, Douglass. Institutions, Institutional Change and Economic Performance, Cambridge University Press, (1990).

[22] Myrdal, Gunnar. Asian Drama: An Inquiry into the Poverty of Nations, The Twentieth Century Fund, (1968).

[23] Pye, Lucian W. The New Asian Capitalism: A Political Portrait, in Peter L. Berger and Hsin-Huang Michael Hsiao (eds. ): In Search of an East Asian Development Model, Transaction Books, (1988).

[24] Rohwer, Jim. Asia Rising, Simon \& Schuster, (1995).

[25] Romar, Edward. Globalization, Ethics, and Opportunism: A Confucian View of Business and Relationships.Business Ethics Quarterly, 14(4), (2004).

[26] So, Alvin Y. and Chiu. W.K. East Asia and the World Economy, Sage Publications, (1995).

[27] Weber, Max. The Protestant Ethic and the Spirit of Capitalism (Translated by Talcott Parsons), Charles Scribner's Sons, (1958).

\section{AUTHORS' BIOGRAPHY}

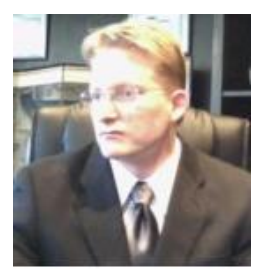

Chris Larsen teaches coursework in comparative culture, international relations, and business, at the Hankuk University of Foreign Studies in Seoul, South Korea. Dr. Larsen is an area expert on Korean culture and language with nearly twenty years teaching, writing, and presenting experience in the field. Inquiries can be directed to larsenprof@gmail.com

Citation: Chris Larsen. "Culture Matters: Confucian Virtues and Economics " International Journal of Humanities Social Sciences and Education (IJHSSE), vol 6, no. 4, 2019, pp. 34-42. doi: http://dx.doi.org/10. 20 431/ 2349-0381.0604006.

Copyright: (C) 2019 Authors. This is an open-access article distributed under the terms of the Creative Commons Attribution License, which permits unrestricted use, distribution, and reproduction in any medium, provided the original author and source are credited. 